\title{
Editorial
}

\section{International Conference on Solar Energy Photovoltaics}

\author{
Udai P. Singh, ${ }^{1}$ Bhushan Sopori, ${ }^{2}$ Pratima Agarwal, ${ }^{3}$ and B. Bhattacharya ${ }^{4}$ \\ ${ }^{1}$ School of Electronics Engineering, Kiit University, Patia, Bhubaneswar 751024, India \\ ${ }^{2}$ National Renewable Energy Laboratory, 15013 Denver West Parkway, Golden, CO 80401-3305, USA \\ ${ }^{3}$ Department of Physics, Indian Institute of Technology Guwahati, Guwahati, Assam 781 039, India \\ ${ }^{4}$ School of Engineering \& Technology, Sharda University, Greater Noida, Uttar Pradesh 201310, India \\ Correspondence should be addressed to Udai P. Singh; singhup@kiit.ac.in
}

Received 11 July 2013; Accepted 11 July 2013

Copyright (C) 2013 Udai P. Singh et al. This is an open access article distributed under the Creative Commons Attribution License, which permits unrestricted use, distribution, and reproduction in any medium, provided the original work is properly cited.

Worldwide, the interest in photovoltaics as an energy technology as well as an industrial opportunity has increased significantly within the last few years, and with the launch of Jawaharlal Nehru National Solar Mission (JNNSM) it has created a lot of interest in the Indian solar sector. To create demand and attract investment in the sector, the government is providing various incentives. India has a huge potential for solar PV and with the right policy support by the Indian Government, India can become a major player in the solar market globally.

The conference was a great success, having 3 keynote lectures, 5 plenary lectures, 12 invited lectures, and 90 contributed papers. The conference was inaugurated by Mr. Arun Kumar Sahoo, Minister of State, Energy, and I\&PR, Government of Odisha, India who emphasizes on energy Security. The guest of honour, Padma Shri Professor A. K. Barua, discussed the status and prospects of solar photovoltaics in India. The conference mainly focuses on device aspects of photovoltaic, involving nearly all the area with a special session on plasmonics and nanostructerd solar cells.

The selected papers for this special issue are representative of the presentation/deliberation during the International Conference on Solar Energy Photovoltaic held at KIIT University, Bhubaneswar, India from 19th to 21st December, 2012.

The special issue has papers focused on alternative buffer layer for polycrystalline thin film solar cells to replace CdS (cadmium sulfide). The focused materials were SnS (tin sulfide) and $\operatorname{In}_{2} \mathrm{~S}_{3}$ (indium sulfide). Few articles emphasize the use of transparent conducting oxide (TCO) for the hybrid and organic solar cell applications. Recently, the focus has been shifted to the use of cheap and abundant elements that make CZTS (copper zinc tin sulfide) as a promising alternative to current solar cells $[1,2]$. Few papers have discussed the preparation of CZTS film using low-cost techniques. Some articles discuss the formation of nanoinks and nanopartilces of CIS (copper indium selenide) and CdSe.

The conference was well supported by the Department of Science and Technology (DST) through its Solar Energy Research Initiative Program, Defence Research and Development Organization (DRDO), Indian Space Research Organization (ISRO), and Hind High Vacuum Pvt. Ltd.

Special thanks go to the Founder of KIIT University, Dr. Achutya Samanta who has encouraged and guided us to make this conference a great success.

Udai P. Singh Bhushan Sopori Pratima Agarwal B. Bhattacharya

\section{References}

[1] Q. Guo, H. W. Hillhouse, and R. Agrawal, "Synthesis of $\mathrm{Cu}_{2} \mathrm{ZnSnS}_{4}$ nanocrystal ink and its use for solar cells," Journal of the American Chemical Society, vol. 131, no. 33, pp. 11672-11673, 2009.

[2] Q. Guo, G. M. Ford, W. C. Yang, C. Hages, H. W. Hillhouse, and R. Agrawal, "Enhancing the performance of CZTSSe solar cells with Ge alloying," Solar Energy Materials \& Solar Cells, vol. 105, pp. 132-136, 2012. 

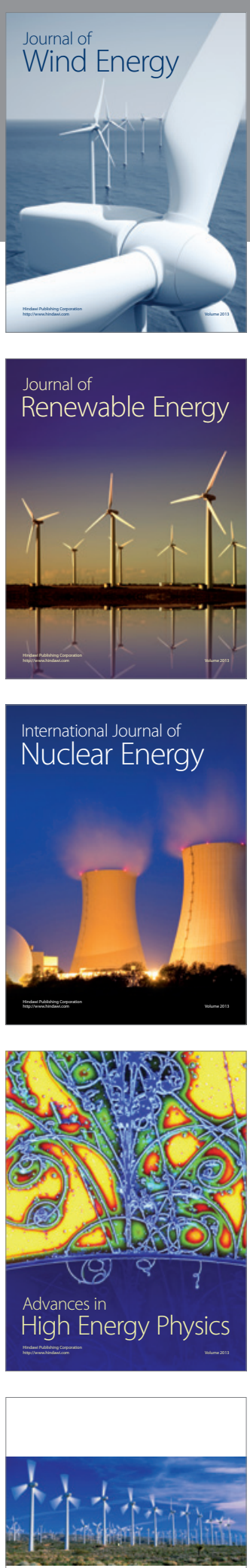

ISRN

Renewable Energy
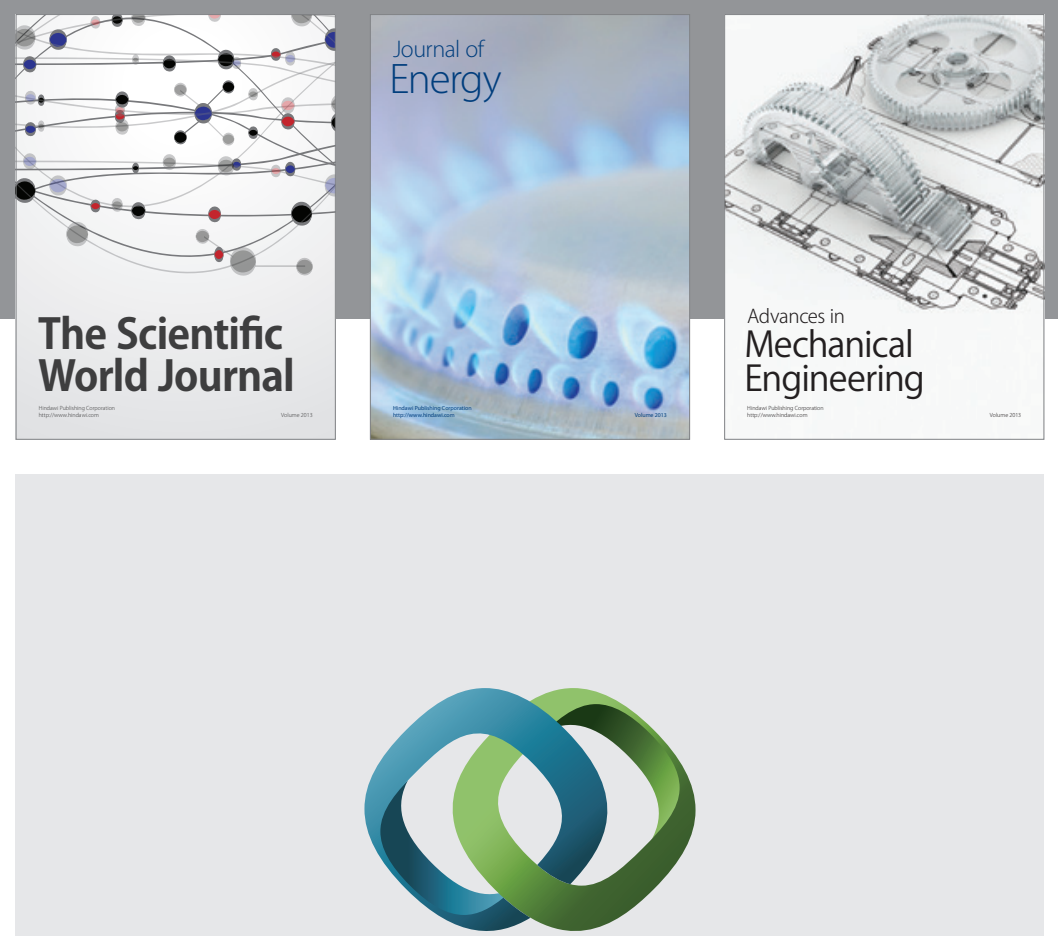

\section{Hindawi}

Submit your manuscripts at http://www.hindawi.com
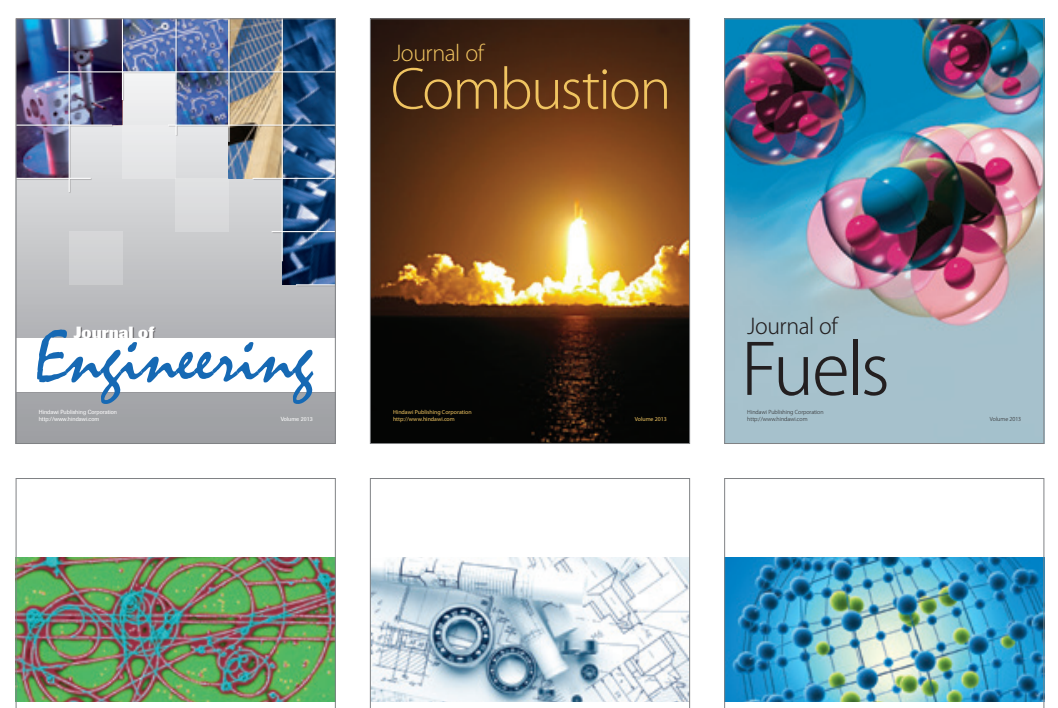

ISRN

High Energy Physics

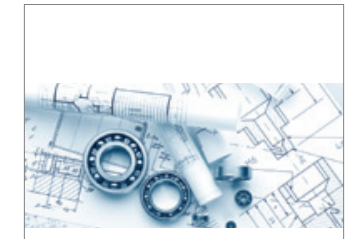

ISRN

Mechanical

Engineering

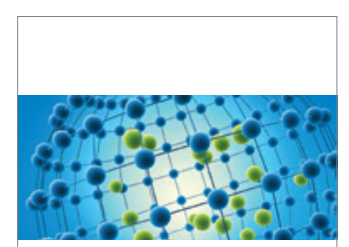

ISRN

Chemical

Engineering
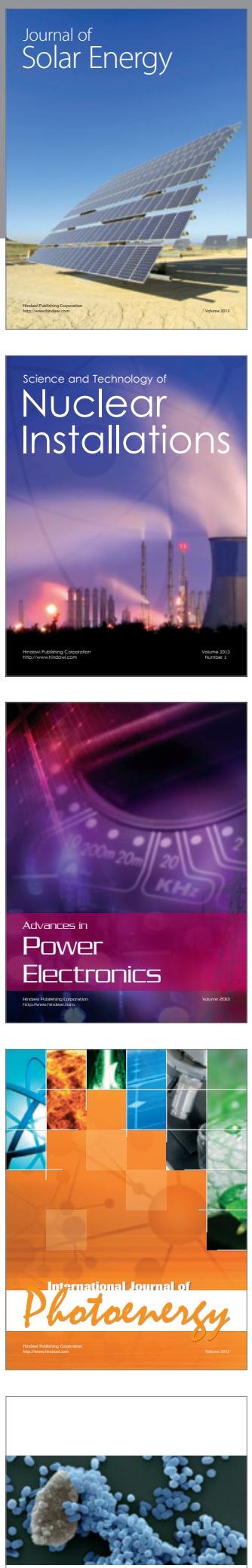

ISRN

Biotechnology 

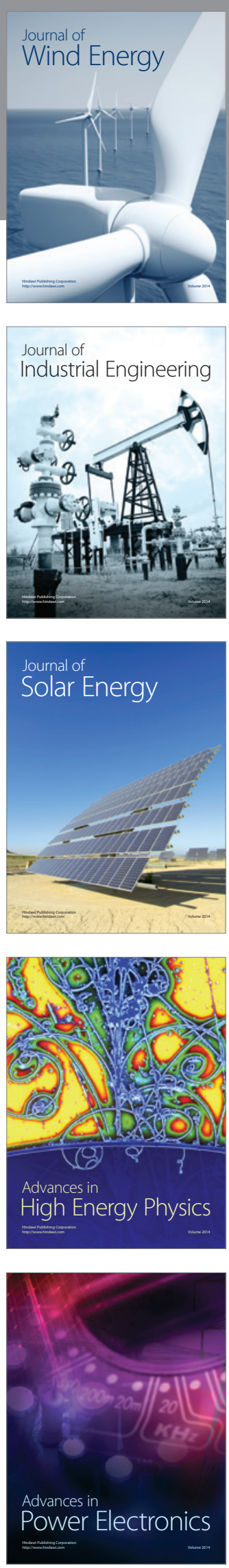
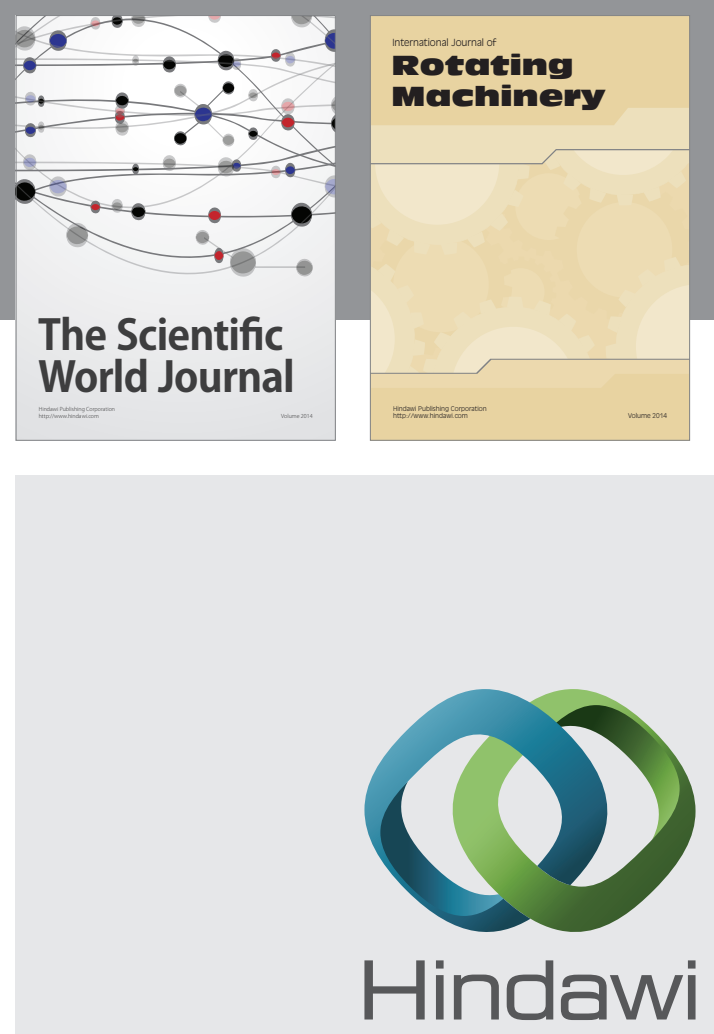

Submit your manuscripts at

http://www.hindawi.com
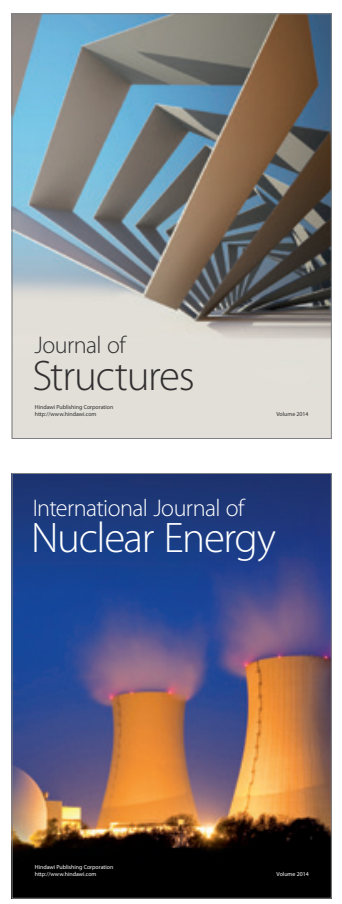
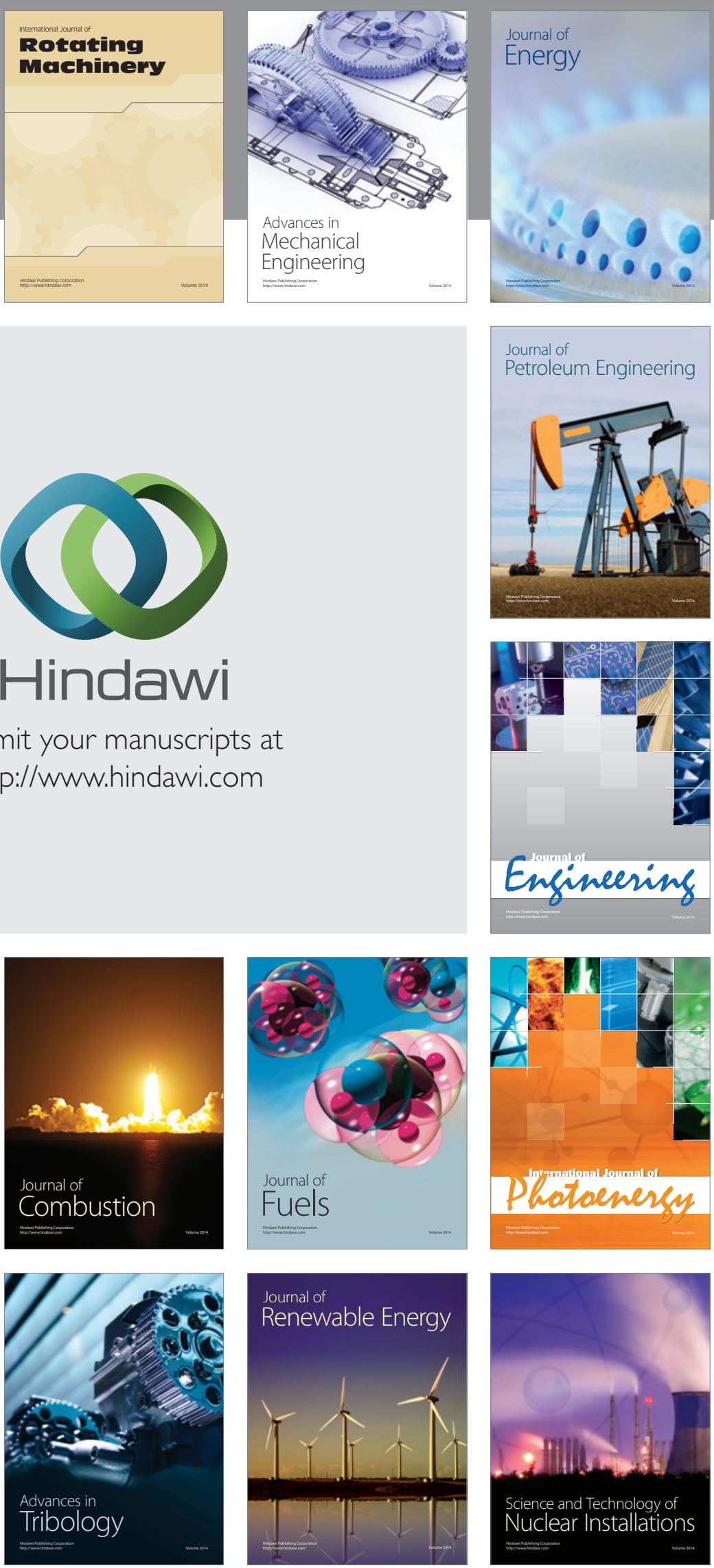